\title{
RESEARCH PAPER EVALUATION OF SURFACE WATER QUALITY CHARAC-
TERISTICS IN OGUN WATERSHED OF SOUTH WESTERN
NIGERIA USING PRINCIPAL COMPONENT ANALYSIS
}

\author{
A. O. Oke ${ }^{1}$ and A. Y. Sangodoyin ${ }^{2}$ \\ ${ }^{1}$ Land and Water Resources Management Programme, Obafemi Awolowo University, \\ Institute of Agricultural Research and Training, \\ PMB 5029, Moor Plantation, Ibadan, Nigeria \\ ${ }^{2}$ Department of Agricultural and Environmental Engineering, Faculty of Technology, \\ University of Ibadan, Ibadan, Nigeria
}

\begin{abstract}
Utilization of water resources across watersheds in Nigeria has been without commensurate attention to protection from degradation at the basin level. One of the strategies in river basin management is effective monitoring and assessment of pollution levels, patterns and identification of major variables driving such degradation most importantly at the watershed scale. Therefore, it is important to evaluate how critical a quality indicator is in its contribution as well as its spatial extent within and across the entire water basin. Twenty six water quality indicators were assessed in Ogun watershed, Nigeria. The nitrogen forms; $\mathrm{TN}, \mathrm{NO}_{3}^{-}$and $\mathrm{NH}_{4}-\mathrm{N}$ were significantly low in the watershed while $\mathrm{TP}$ and $\mathrm{PO}_{4}{ }^{3-}$ were higher $(\mathrm{p}<0.05)$. The $\mathrm{BOD}_{5}$ and $\mathrm{COD}$ were significantly high which explains the low DO observed in the watershed. High levels of Fe, $\mathrm{Cd}$, $P b$, Mn as well as E-coli and Fecal Coliform were recorded. Using Principal Component Analysis (PCA), 77\% (20 out of 26) of the water quality indicators examined were found to be critical. These explained more than $90 \%$ of the observed water quality variation across the watershed. The variable inclusion level showed that these parameters were critical in $70 \%$ of the locations across the watershed. The selection of 77\% of the parameters investigated by PCA over $70 \%$ of the locations revealed high levels of diffused pollution that calls for urgent attention.
\end{abstract}

Keywords: Principal Component Analysis, Ogun watershed, Water Quality, Pollution, Nigeria

\section{INTRODUCTION}

Diffused pollution in watersheds in Nigeria has been reported to be critical (Adedokun et al., 2008). Ajibade(2004)observed that the Asa River in Ilorin, north central Nigeria was polluted while Jaji et al.(2007) in their study of Ogun river in the south west of the country came up with similar conclusions. To achieve a shift from the current practices of location targeted assessment, holistic water quality assessment at the watershed level is recommended (Emmanuel et al., 2010). Whereas, the OgunRiver has been inconsistently monitored at different reaches in an uncoordinated manner (Martins and Awokola, 1996; Jaji et al., 2007), River Ofiki, the second major river in Ogun 
watershed which serves as the major source for the dry season agricultural activities and domestic water supply for the agrarian community of Oke-Ogun South Western Nigeria has not been adequately assessed and reported.

An assessment of river water quality using multivariate analysis will enhance the understanding of the pattern of water quality across watersheds (Shreshta and Kazama, 2007). The advantages of multivariate statistics include its capacity to consider complex data arrays and identify patterns otherwise difficult to understand by simple relationships (Cansu et al., 2009).

Principal Component Analysis (PCA) has been used in water resources research to identify major elements responsible for observed variation in surface and groundwater as well as sediment quality in watersheds (Karim and Taha, 2003; Ouyang et al., 2006; Harley et al., 2009). This tool enables the assessment of the relevance of water quality indicator to an environment and justifies its inclusion in the monitoring and assessment scheme to avoid under estimation of levels of water quality impairment.

This study assesses the level of quality impairment using PCA to identify critical water quality indicators with utmost concern in the river systems within Ogun watershed Southern, Nigeria.

\section{METHODOLOGY}

\section{The Ogun Watershed}

The Ogun watershed covers approximately $23,0447 \mathrm{~km}^{2}$ and is drained principally by Rivers Ogun and Ofiki (Fig. 1). The rivers have several tributaries including Oyan, Ona and Opeki (OORBDA, 1996). Rivers Ogun and Ofiki were assessed using longitudinal profile technique (Meybeck et al., 1996) across10 locations, which correspond to the established gauging stations in the watershed. The 10 sampling points met the requirement of thorough mixing, representativeness and accessibility (Fig. 1). The locations are: OG1, OG2, OG3, OG4, OG5 and OG6 on Ogun River; and OF1,
OF2, OF3, and OF4 on Ofiki River.

\section{Laboratory analysis}

Grab sampling method (Meybeck et al., 1992) was employed in river water sample collection. Samples were stored in high-density polyethylene plastic bottles. The bottles were pre-rinsed with $1+\mathrm{HNO}_{3}$ (APHA, 1998) before rinsing with river water at the sampling point. Twentysix water quality parameters were examined. These include: Temperature, Electrical Conductivity (EC), pH, Dissolved Oxygen (DO), 5 days Biochemical Oxygen Demand $\left(\mathrm{BOD}_{5}\right)$, Chemical Oxygen Demand (COD), Total Acidity, Turbidity, Total Suspended Solid (TSS), Ammonium-Nitrogen, Nitrate-Nitrogen, Nitrite -Nitrogen, Total Nitrogen (TN), Total Phosphorous (TP), Phosphate $\left(\mathrm{PO}_{4}{ }^{3-}\right)$, Iron (Fe), Cadmium (Cd), Zinc (Zn), Mercury (Hg), Copper $(\mathrm{Cu})$, Manganese $(\mathrm{Mn})$, Lead $(\mathrm{Pb})$, Chromium (Cr), Total Viable Bacteria Count (TVC), Euchearia coliform (E-Coli) and Fecal Coliform (Fcol).

Samples were taken monthly for 12 months covering a hydrological season and were kept at $<4^{\circ} \mathrm{C}$ using ice parks in mobile cooler. Standard methods (APHA, 1998) were used in laboratory analyses, which include Atomic Absorption Spectrophotometry, Kjeldhal and Colorimetric methods (digestion, washing and addition of reagents for color development). Analyses were accomplished within 48hours after sampling. However, Temperature, EC, $\mathrm{pH}$ and DO were taken in situ using Hanna HI98130 meter.

\section{Statistical analysis}

Annual average value of each variable was computed while comparisons were made of the water quality variables with the Nigerian Industrial Standard (NIS, 2007), and World Health Organization (WHO, 2011) drinking water guidelines using the more stringent guide in each case. Drinking water guide was employed because river water for domestic abstraction is still a major demand in the watershed. The student's t-test was used for the mean comparison 


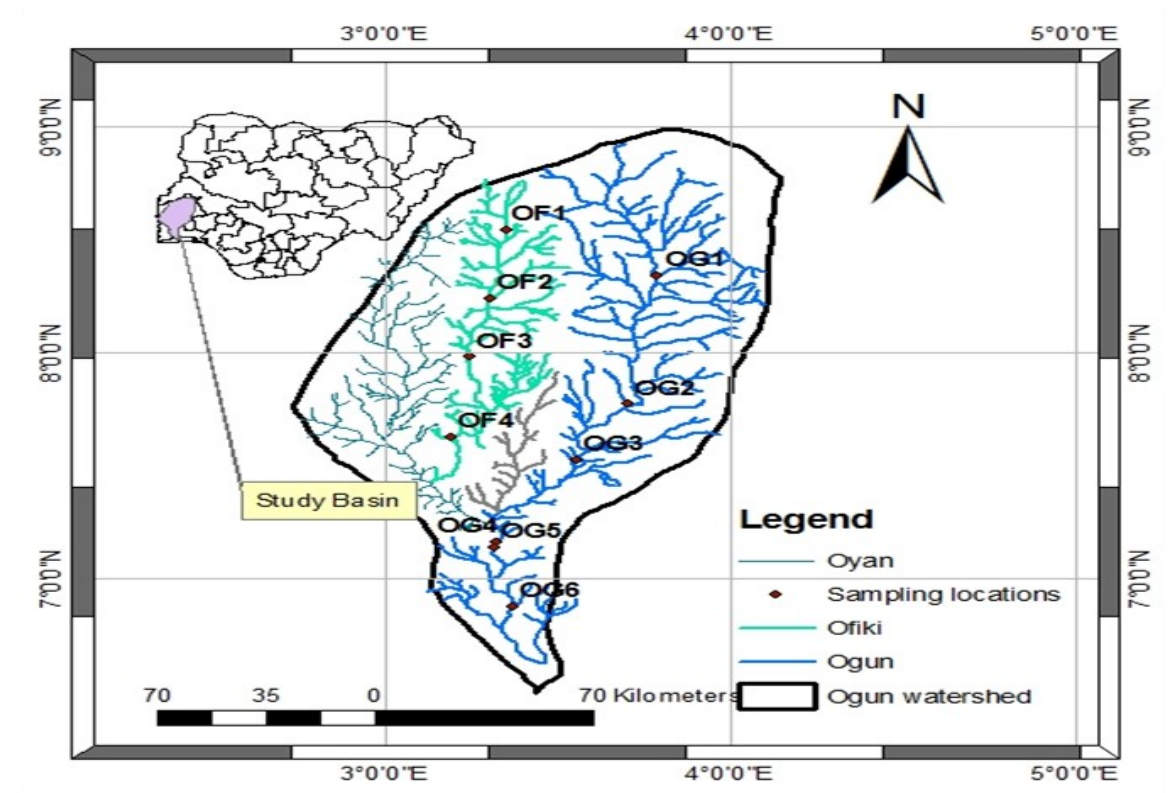

Fig. 1: Location map of Ogun watershed

given matrix (Ouyang et al., 2006; Cansu et al., 2009).

$z_{i j}=a_{i 1} x_{1 j}+a_{i 2} x_{2 j}+a_{i 3} x_{3 j}+\cdots+a_{i m} x_{m j}$

where:

$\mathrm{a}=$ component loading

$\mathrm{z}=$ component score

$\mathrm{x}=$ measured value of a variable (water quality

concentration)

$\mathrm{i}=$ component number

$\mathrm{j}=$ sample number

$\mathrm{m}=$ total number of variables

The data matrix for each location was 12 months by 26 water quality variables. The PCA relies upon an eigenvector decomposition of the covariance or correlation matrix (Ouyang et al., 2006)In this study, only factors exhibiting an eigenvalue greater than unity were retained (Shresta and Kazama, 2007). Scree plots of the made to determine the principal components (PC) that meet the eigen value criterion. Also, a varimax rotation was performed to address the problem of variables loading moderately or equally on one or more of the axes. A secured increased PCs significance is the consequence of this rotation on the interpretation of the results (Karim and Taha, 2003; Ouyang et al., 2006). Using the component loading factor, a variable with factor loading more than 0.70 was considered to be significant (Shreshta and Kazama, 2007).The percentage of locations where a variable was listed as significant in PCs was noted as its Variable Inclusion Level (VIL) in the watershed (Equation 2). Variables with $70 \%$ VIL and above were taken as parameter of major concern in monitoring water quality variation in the watershed. 
Variable inclusion level $=\frac{\text { No of locations where a variable is included in the PCs }}{\text { Total no of locations studied in the watershed }} \times 100 \%$

\section{RESULTS AND DISCUSSION Water quality characteristics}

The annual mean water quality indicators are shown in Table 1. The EC and $\mathrm{pH}$ across the locations ranged from $1.15-1.25 \mathrm{dS} / \mathrm{m}$ and 6.9 -7.1 , respectively. Conductivity and $\mathrm{pH}$ were not significantly higher than the expected maximum of $10 \mathrm{dS} / \mathrm{m}$ and $6.5-11.0$ respectively. This shows that water quality in terms of acidity is adequate for agricultural purposes. The minimum and maximum water temperatures across the watershed ranged from $21-23^{\circ} \mathrm{C}$ and $26-30^{\circ} \mathrm{C}$, respectively. Higher temperature was observed during the period of low rainfall. This may be due to increasing anaerobic digestion of deposited bio-degradable materials in the river system according to Ruth and Mathew (2003).

The DO was quite low across the basin (1.98 $2.64 \mathrm{mg} / 1)$. Relatively higher values were recorded during the wet seasons. The low level of DO is related to high level of organic wastes in the river systems (Gilbert, 1996). This was evidenced in high $\mathrm{BOD}_{5}$ and $\mathrm{COD}$ which were significantly higher $(\mathrm{p}<0.01)$ than the limits set by $\mathrm{WHO}$. The recorded mean value of $\mathrm{BOD}_{5}$ in Ogun watershed ranged between $31.1 \mathrm{mg} / \mathrm{l}$ in OG1 and $41.2 \mathrm{mg} / \mathrm{l}$ in OG4, which are within agricultural and urban land-use respectively. A similar trend was observed in the values of COD. High levels of biodegradable organic materials adversely affects DO since available oxygen is used up in the oxidation process (Gilbert, 1996).

Turbidity (Turb) and TSS across the watersheds generally exceeded the acceptable limits of $5.0 \mathrm{mg} / \mathrm{l}$ and $25 \mathrm{mg} / \mathrm{l}$ respectively (Table 2). Across all locations in Ogun and Ofiki rivers, there were high levels of turbidity occasioned consequence is a decrease in light penetration to the river systems. These give the river poor aesthetic value with potential to increase sedimentation in reservoirs within the watershed. Emmanuel et al., (2010) had observed negative impact of discharged effluent from a wastewater treatment plant on a receiving watershed in South Africa.

The Nitrogen forms were generally lower than the limits set in NIS and WHO guides (Table 2). This suggest that Nitrogen based nutrient pollution may not be a major challenge in the watershed. However, the level of phosphate $(11.9-14.1 .9 \mathrm{mg} / \mathrm{l})$ was significantly $(P<0.01)$ higher than the limits of $0.02 \mathrm{mg} / \mathrm{l}$. Similarly, TP was higher than the expected $5.0 \mathrm{mg} / 1$ across all the locations. Phosphate levels in the watershed could be linked to discharge of wastewater and runoff from farmlands using phosphatebased fertilizers in addition to the natural occurrence of phosphorous in the watershed. Impacts of nutrient pollution in the surface water of sub-Saharan Africa have generally been identified (Nyenje et al., 2010) with the impact of phosphorous being more pronounced in Ogun watershed.

With the exception of $\mathrm{Zn}, \mathrm{Cu}$ and $\mathrm{Cr}$, it was observed that the annual mean concentration of other metals across the watershed was significantly $(P<0.01)$ higher than the limits set for each of the variables (Table 2). This elevated metal concentration should be of major concern for human health (GEMS, 2007). Farmers depend on the river water for irrigation and crops are prone to elevated metal uptake from irrigated soil with attended risk for consumers (Oluwatosin et al., 2009; Fiona et al., 2010).

The bacteria loads were significantly $(P<0.01)$ higher than the $10 \mathrm{cfu} / 100 \mathrm{ml}$ limit. Specific 
Evaluation of surface water quality characteristics in Ogun Watershed...

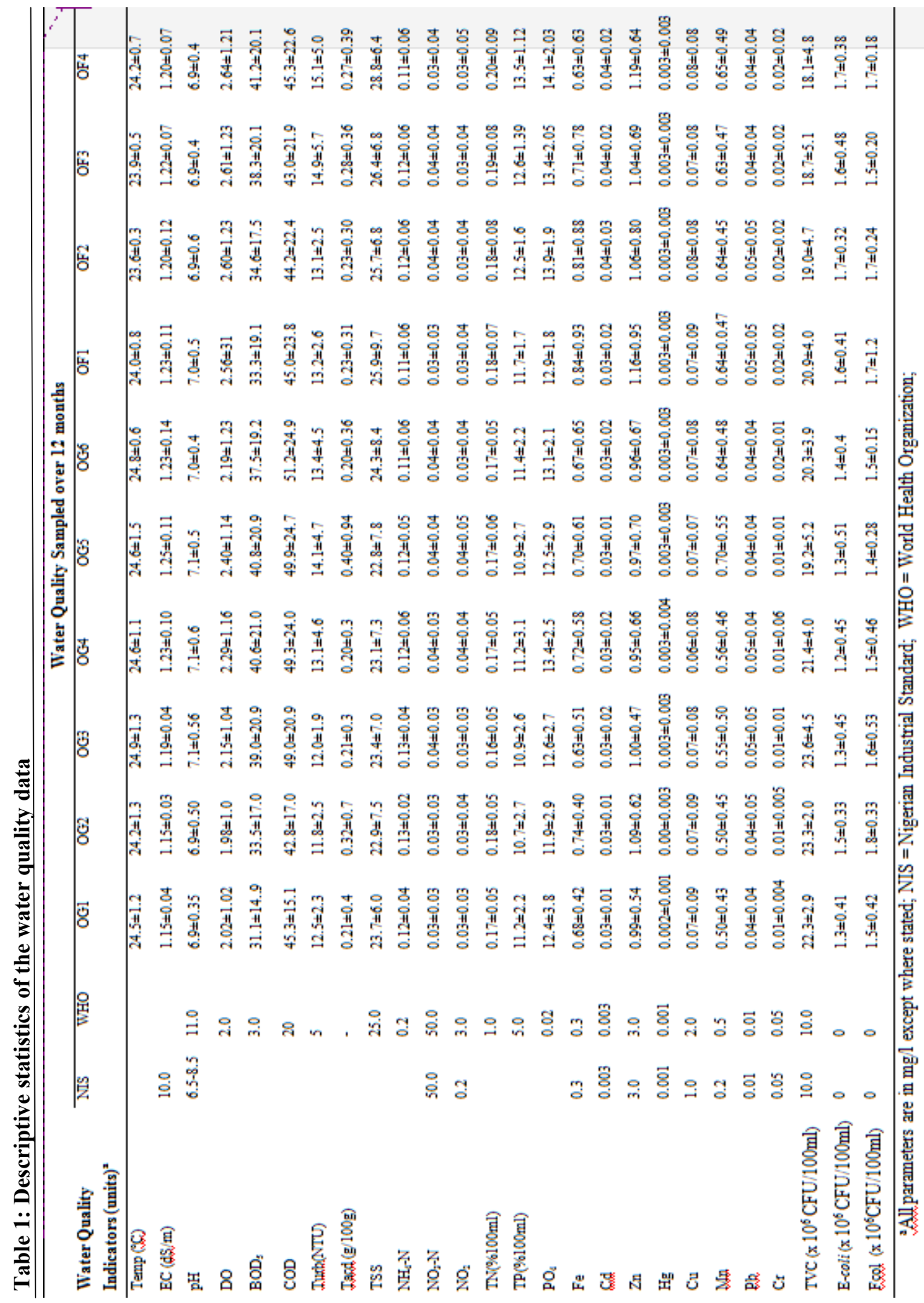


Table 2 : Comparison of data average with guide values of maximum allowable limits

\begin{tabular}{|c|c|c|c|c|c|}
\hline Variables (units ${ }^{\mathrm{e}}$ ) & Test guide value & $\operatorname{sig} \uparrow^{a}$ & $\mathbf{n s} \uparrow^{b}$ & $\operatorname{sig} \downarrow^{c}$ & $n s \downarrow^{d}$ \\
\hline Temp $\left({ }^{\circ} \mathrm{C}\right)$ & - & & & & \\
\hline $\mathrm{EC}(\mathrm{dS} / \mathrm{m})$ & 3.0 & & & $*$ & \\
\hline $\mathrm{pH}$ & 6.5 & & $*$ & & \\
\hline DO & 2.0 & & $*$ & & \\
\hline $\mathrm{BOD}_{5}$ & 3.0 & $*$ & & & \\
\hline COD & 3.0 & $*$ & & & \\
\hline Turb (NTU) & 5.0 & $*$ & & & \\
\hline Tacd $(\mathrm{g} / 100 \mathrm{~g})$ & - & & & & \\
\hline TSS & 25 & $*$ & & & \\
\hline $\mathrm{NH}_{4}-\mathrm{N}$ & 0.2 & & & $*$ & \\
\hline $\mathrm{NO}_{3}-\mathrm{N}$ & 50.0 & & & $*$ & \\
\hline $\mathrm{NO}_{2}$ & 0.2 & & & $*$ & \\
\hline $\mathrm{TN}(\% 100 \mathrm{ml})$ & 1.0 & & & $*$ & \\
\hline $\mathrm{TP}(\% 100 \mathrm{ml})$ & 5.0 & $*$ & & & \\
\hline $\mathrm{PO}_{4}$ & 0.02 & $*$ & & & \\
\hline $\mathrm{Fe}$ & 0.3 & $*$ & & & \\
\hline $\mathrm{Cd}$ & 0.003 & $*$ & & & \\
\hline $\mathrm{Zn}$ & 3.0 & & & $*$ & \\
\hline $\mathrm{Hg}$ & 0.001 & $*$ & & & \\
\hline $\mathrm{Cu}$ & 1.0 & & & $*$ & \\
\hline $\mathrm{Mn}$ & 0.2 & $*$ & & & \\
\hline $\mathrm{Pb}$ & 0.01 & $*$ & & & \\
\hline $\mathrm{Cr}$ & 0.05 & & & $*$ & \\
\hline $\operatorname{TVC}\left(\mathrm{x} 10^{6}\right.$ & 10.0 & $*$ & & & \\
\hline \multicolumn{6}{|l|}{ CFU/100ml) } \\
\hline E-coli $\left(\times 10^{6}\right.$ & 0 & $*$ & & & \\
\hline \multicolumn{6}{|l|}{$\mathrm{CFU} / 100 \mathrm{ml})$} \\
\hline Fcol $(x$ & 0 & $*$ & & & \\
\hline $\left.10^{6} \mathrm{CFU} / 100 \mathrm{ml}\right)$ & & & & & \\
\hline
\end{tabular}

${ }^{a}$ significantly higher $(p<0.01) ;{ }^{b}$ not significantly higher $(p<0.01) ;{ }^{c}$ significantly lower $(p<0.01){ }^{d}$ not significantly lower $(p<0.01) ;{ }^{e}$ All parameters in $\mathbf{m g} / \mathbf{l}$ except where stated

assay of E-coli and fecal coliform across the watershed also revealed a significantly high level of pathogenic load. The rural communities bordering the Ogun and Ofiki watershed still meet their water need mainly from rivers and streams without any form of treatment. This poses a high risk of water borne and water related diseases to the communities within the watershed. The high pathogenic loads across the watershed may be linked to unregulated cattle grazing and wash off of cattle dung, indiscriminate poultry and other solid wastes into the river systems.

\section{Principal components analysis across the lo-} cations

The scree plots of eigen values generated in the analysis were used in determining the appropriate principal components (PCs) to be considered. Fig. 2 and Fig. 3 show the scree plots ob- 
tained from the eigen values for OG1 and OG2data respectively. Considering eigen values $>1.0$ as proposed by Shresta and Kazama (2007), component numbers $1-4$ (Fig. 2) met the criteria.The4PCs selected for the analysesi.e.PC1 - PC4, accounted for 58, 19, 8 and $7 \%$ thus totaling $93 \%$ of the total variance of information contained in the original dataset for the location. Similarly, the scree plot for location 2 (OG2) on the Ogun river (Fig. 3) show five PCs with eigen values $>1.0$ ( $\mathrm{PC} 1-\mathrm{PC} 5)$, and therefore selected for further analysis at this location. The PC1-PC5 explained 54, 23, 8,6 and $5 \%$ totaling $96 \%$ of the total variance of information contained in the original dataset for the location.

With PC extractions, the selected indicators were able to give substantial explanation of the observed variation without losing or distorting the complete picture of the data set. In OG1, the parameters in the PCs explained $93 \%$ of the variation observed, thus, the remaining $7 \%$ variation was explained by excluded indicators. The excluded indicators are not significant enough to affect the observed variation in the location. Karim and Taha (2003) have also used the strength of PCA to identify the drivers of variation and listing them as PCs.

The indicators constituting the PCs for location 1 (OG1) are presented in Table 3. PC1, which explains $58 \%$ of the variation observed at this location had heavy metals, conductivity and total viable counts as the major water quality indicators. The PC2 had Temperature, COD, Phosphate, heavy metals ( $\mathrm{Zn}$ and $\mathrm{Hg}$ ) and Fecal coliform as responsible for the observed $19 \%$ of the variation within the location. Organic constituent $\left(\mathrm{BOD}_{5}\right)$, which has direct influence on dissolved oxygen depletion in the water body and E-coli level in the river, explains $8.5 \%$ while turbidity accounted for $7 \%$ of the observed variation in the location. The contribution of PC1 shows that heavy metal pollution is a major consideration within OG1 in Ogun

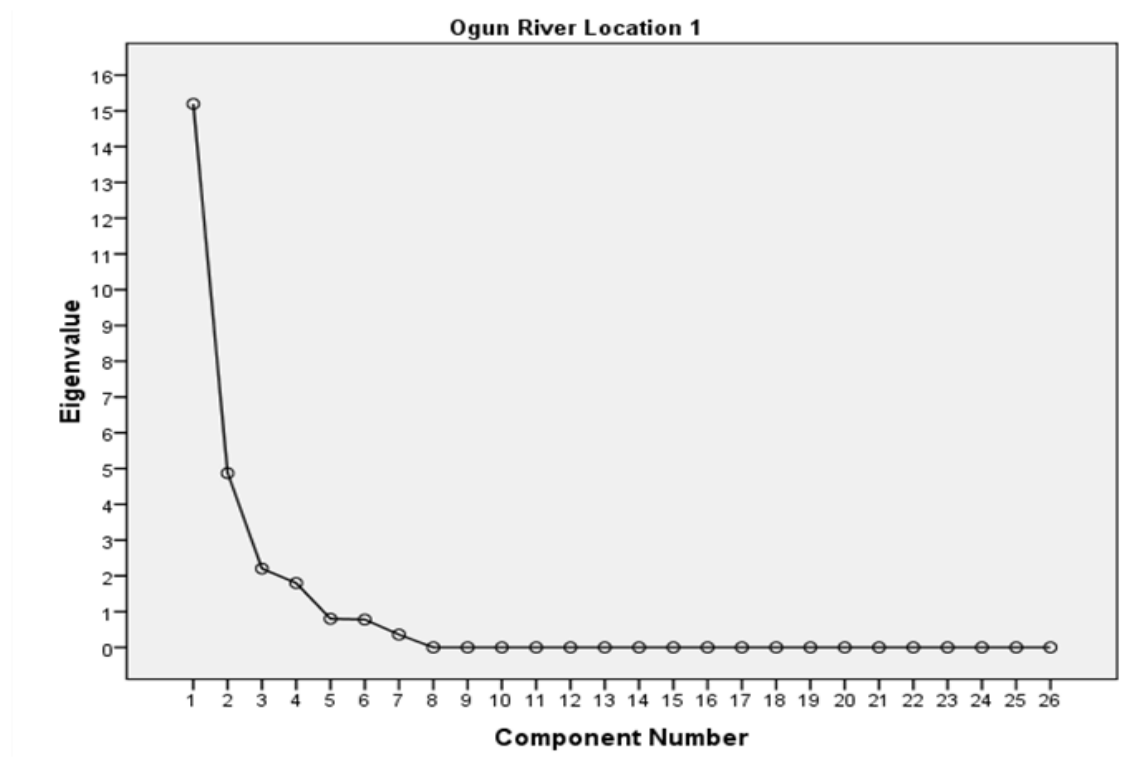

Fig. 2: Scree plot for delineation of PCs for location 1 on the Ogun River

Journal of Science and Technology $\mathbb{C}$ KNUST April 2015 


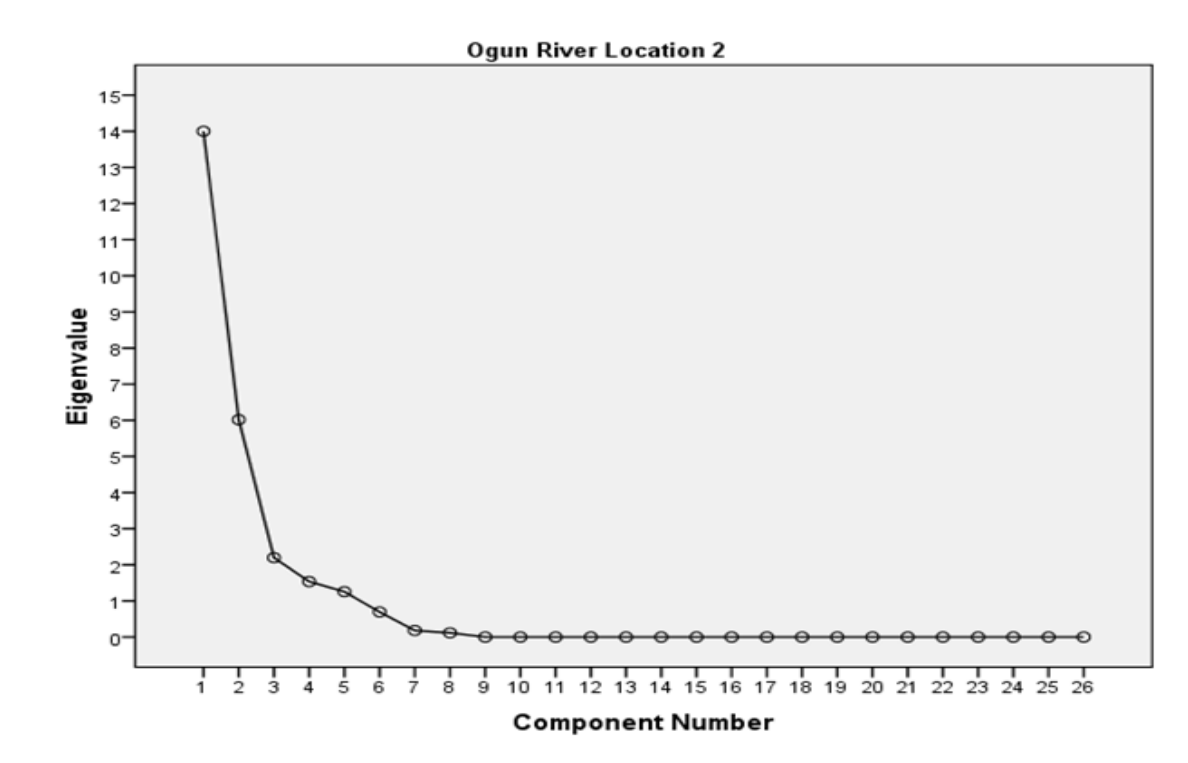

Fig. 3: Scree plot for delineation of PCs for location 2 on the Ogun River

River section of the watershed. Although industrial activities within the watershed are minimal, the land-use is mainly agricultural and the impact of $\mathrm{Fe}, \mathrm{Pb}, \mathrm{Cd}, \mathrm{Cr}$ and $\mathrm{Mn}$ are significant. These heavy metals might have been from traffic and agricultural bio-chemical inputs, in addition to possible natural sources (Emoyan et al., 2006).

The water quality indicators constituting each of the PCs in OG2 are listed in Table 4. The major indicators of water quality variation in PC1 are nitrogen compounds, phosphate and heavy metals, which together explain $53.8 \%$ of the variations. This principal component reflects nutrient and heavy metals $(\mathrm{Fe}, \mathrm{Cd}, \mathrm{Zn}$, $\mathrm{Cu}, \mathrm{Mn}, \mathrm{Pb}$ ) pollutants in the location. For $\mathrm{PC} 2$, which explains $23.1 \%$ of the variation, the impact of organic load and particulate influx was evident while PC3 and PC5 have indicators of microbiological pollutants and conductivity. Agricultural land-use is predominant in this location while human settlement is dispersed comprising mainly of farmlands and villages.
The observation of nutrient pollution is related to the use of organic and inorganic fertilizers. Iron and Zinc could be from natural occurrence while $\mathrm{Cd}$ may be related to the use of inorganic fertilizers (Nyenje et al., 2010). Similar to the upstream location (OG1) where heavy metals constitute part of the major pollutants observed, the use of PCA has revealed the influence of heavy metals as critical in water quality variation across the locations.

\section{Component loading factor}

Component loadings are the linear combinations for each principal component. It expresses the correlation between the original variables and the newly formed components. The components loadings are used to determine the relative importance of a variable under consideration as compared to other variables in a PC and do not necessarily reflect the importance of the component itself (Ouyang et al., 2006). The varimax rotated component loadings for the observed variables listed in the PCs in OG1, which were considered significant at $>0.70$ are 
Evaluation of surface water quality characteristics in Ogun Watershed... 97

Table 3: Principal components explaining water quality variation in location 1 of Ogun River

\begin{tabular}{lllll}
\hline & PC1 & PC2 & PC3 & PC4 \\
\hline & $\mathrm{EC}$ & $\mathrm{Temp}$ & $\mathrm{DO}$ & Turbidity \\
& $\mathrm{NO}_{2}$ & $\mathrm{COD}$ & $\mathrm{BOD}_{5}$ & Tacd \\
$\mathrm{Fe}$ & $\mathrm{PO}_{4}$ & E-coli & \\
$\mathrm{Cd}$ & $\mathrm{Zn}$ & & \\
$\mathrm{Cu}$ & $\mathrm{Hg}$ & & \\
$\mathrm{Mn}$ & $\mathrm{F} \mathrm{col}$ & & \\
& $\mathrm{Pb}$ & & & \\
& $\mathrm{Cr}$ & & & \\
& $\mathrm{TVC}$ & & & \\
& 15.194 & 4.87 & 2.203 & 1.798 \\
Total Eigen value & 58.439 & 18.73 & 8.473 & 6.915 \\
\% of Variance & 58.439 & 77.169 & 85.642 & 92.557 \\
Cumulative \% & & & & \\
\hline
\end{tabular}

Table 4: Principal components explaining water quality variation in location 2 of Ogun River

\begin{tabular}{|c|c|c|c|c|c|}
\hline & PC1 & PC2 & PC3 & PC4 & PC5 \\
\hline & $\mathrm{NO}_{3}$ & $\overline{\mathrm{DO}}$ & Temp & Tacd & $\mathrm{TVC}$ \\
\hline & $\mathrm{NO}_{2}$ & $\mathrm{BOD}_{5}$ & $\mathrm{Ec}$ & & \\
\hline & $\mathrm{TN}$ & COD & Ecol & & \\
\hline & $\mathrm{PO}_{4}$ & Turb & Fcol & & \\
\hline & $\mathrm{Fe}$ & TSS & & & \\
\hline & $\mathrm{Cd}$ & $\mathrm{Hg}$ & & & \\
\hline & $\mathrm{Zn}$ & $\mathrm{Cr}$ & & & \\
\hline & $\mathrm{Cu}$ & & & & \\
\hline & $\mathrm{Mn}$ & & & & \\
\hline & $\mathrm{Pb}$ & & & & \\
\hline Total Eigen values & 14.00 & 6.02 & 2.20 & 1.536 & 1.255 \\
\hline$\%$ of Variance & 53.85 & 23.14 & 8.449 & 5.907 & 4.828 \\
\hline Cumulative \% & 53.85 & 76.99 & 85.439 & 91.346 & 96.174 \\
\hline
\end{tabular}

shown in Fig. 4. Variables with such level of loadings were considered critical. The contributions from each of the PCs were different. In terms of percentage contributions to the variation, however, the listed parameters in each of the PCs all have high component loading factors $(>0.70)$. High loading factors confer on the variable a high level of significance (Shreshta and Kazama, 2007). Fig. 5 similarly shows the component loading for the indicators 


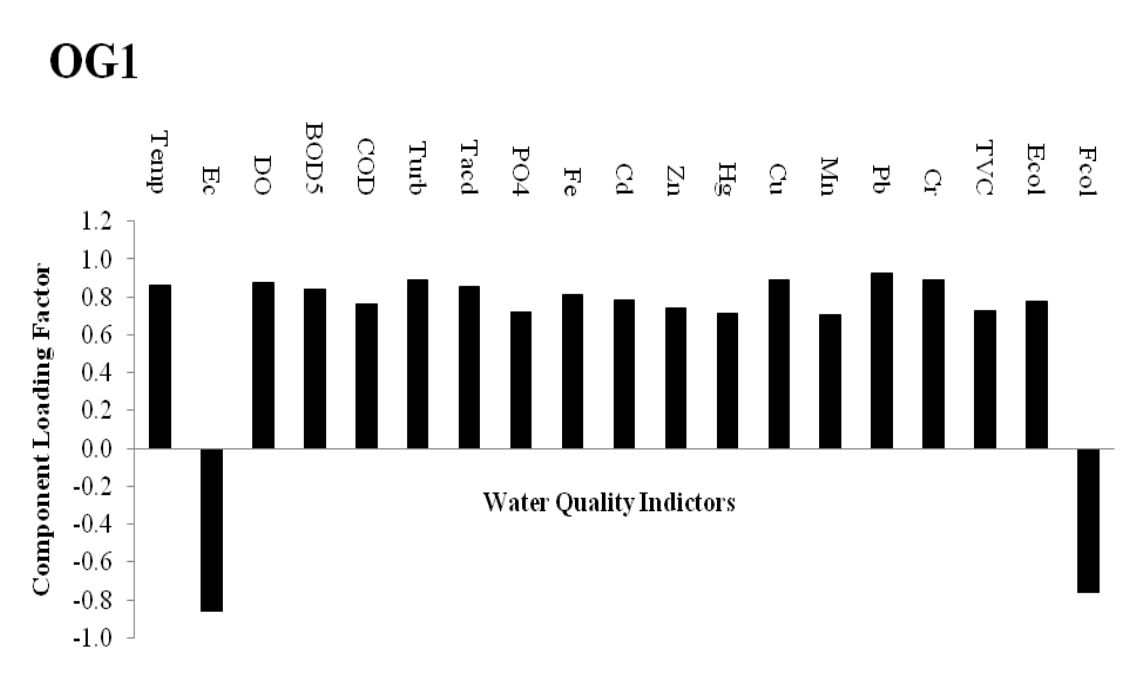

Fig. 4: Factor loading for location OG1 on Ogun River

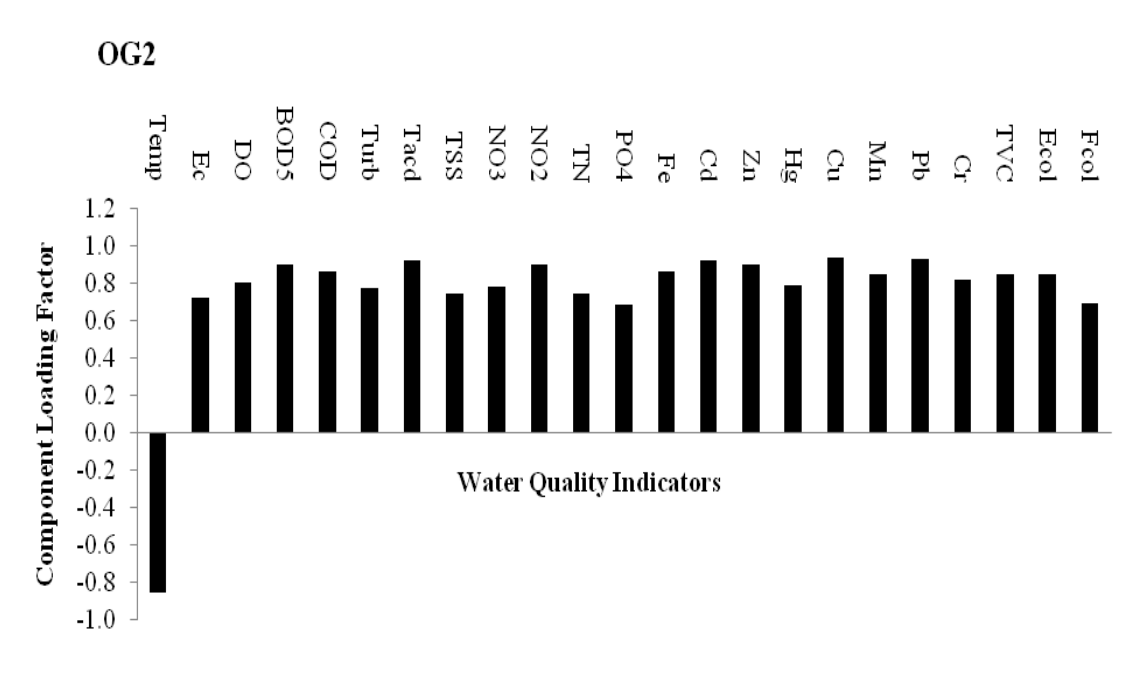

Fig. 5: Factor loading for location OG2 on Ogun River

identified in the PCs of OG2.

Other locations in Ogun Watershed

The summary of the contribution of variation and number of indicators implicated across the locations OG3, OG4, OG5 and OG6 on Ogun and OF1, OF2, OF3 and OF4 on Ofiki Rivers are presented in Table 5. The Ofiki River 
mainly drains agricultural and sub-urban settlements without much control of organic and inorganic fertilizer use, agrochemical inputs, grazing and sanitary systems. Indiscriminate disposal of dry cell batteries used by farmers to power transistor radios also increases the risk of $\mathrm{Pb}$ and $\mathrm{Cd}$ in the surface water system. The PCs generated for locations across Ofiki Rivers had a very close similarity to that obtained along Ogun River. Heavy metals were mainly listed in the PC1 for each of the locations showing the contribution and strategic importance of heavy metals as a pollutant in the Ogun and Ofiki river systems. Nutrients (TN,
$\left.\mathrm{TP}, \mathrm{PO}_{4}\right)$, Organic load $\left(\mathrm{BOD}_{5}, \mathrm{COD}\right)$ physical parameters (Turbidity, TSS, DO, Temperature) as well as E-coli and Fecal coliform are the major pollutants. These accounted for a high percentage $(>90 \%)$ of the observed water quality variation in these rivers. Similarly, the component factor loadings of variables in PCs of Ofiki River are equally high.

Variable inclusion level and critical indicators in the watershed

Table 5 shows that in all the locations, between 90 and $96 \%$ of the variations were accounted for by the parameters listed under each loca-

Table 5: Summary of the PCA identified water quality indicators listed at each of the Locations and the Variable Inclusion Level (VIL)

\begin{tabular}{|c|c|c|c|c|c|c|c|c|c|c|c|}
\hline & OG1 & OG2 & OG3 & OG4 & OG5 & OG6 & OF1 & OF2 & OF3 & OF4 & VIL \\
\hline Temp & $\sqrt{ }$ & $\sqrt{ }$ & & & $\sqrt{ }$ & $\sqrt{ }$ & $\sqrt{ }$ & & $\sqrt{ }$ & & 60.0 \\
\hline $\mathrm{EC}$ & $\sqrt{ }$ & $\sqrt{ }$ & & & $\sqrt{ }$ & & $\sqrt{ }$ & & $\sqrt{ }$ & & 50.0 \\
\hline $\mathrm{pH}$ & & & $\sqrt{ }$ & & & $\sqrt{ }$ & $\sqrt{ }$ & $\sqrt{ }$ & & $\sqrt{ }$ & 50.0 \\
\hline DO & $\sqrt{ }$ & $\sqrt{ }$ & $\sqrt{ }$ & $\sqrt{ }$ & $\sqrt{ }$ & $\sqrt{ }$ & $\sqrt{ }$ & $\sqrt{ }$ & $\sqrt{ }$ & $\sqrt{ }$ & 100.0 \\
\hline $\mathrm{BOD}_{5}$ & $\sqrt{ }$ & $\sqrt{ }$ & $\sqrt{ }$ & $\sqrt{ }$ & $\sqrt{ }$ & & $\sqrt{ }$ & $\sqrt{ }$ & $\sqrt{ }$ & $\sqrt{ }$ & 90.0 \\
\hline COD & $\sqrt{ }$ & $\sqrt{ }$ & $\sqrt{ }$ & $\sqrt{ }$ & $\sqrt{ }$ & & $\sqrt{ }$ & $\sqrt{ }$ & $\sqrt{ }$ & $\sqrt{ }$ & 90.0 \\
\hline Turb & $\sqrt{ }$ & $\sqrt{ }$ & $\sqrt{ }$ & $\sqrt{ }$ & $\sqrt{ }$ & $\sqrt{ }$ & & $\sqrt{ }$ & $\sqrt{ }$ & $\sqrt{ }$ & 90.0 \\
\hline Tacd & & $\sqrt{ }$ & $\sqrt{ }$ & $\sqrt{ }$ & $\sqrt{ }$ & $\sqrt{ }$ & $\sqrt{ }$ & $\sqrt{ }$ & $\sqrt{ }$ & $\sqrt{ }$ & 90.0 \\
\hline TSS & & & & $\sqrt{ }$ & & & $\sqrt{ }$ & $\sqrt{ }$ & & $\sqrt{ }$ & 40.0 \\
\hline $\mathrm{NH}_{4}-\mathrm{N}$ & & & $\sqrt{ }$ & $\sqrt{ }$ & & $\sqrt{ }$ & $\sqrt{ }$ & $\sqrt{ }$ & $\sqrt{ }$ & $\sqrt{ }$ & 70.0 \\
\hline $\mathrm{NO}_{3}-\mathrm{N}$ & & $\sqrt{ }$ & $\sqrt{ }$ & $\sqrt{ }$ & $\sqrt{ }$ & $\sqrt{ }$ & & $\sqrt{ }$ & $\sqrt{ }$ & & 70.0 \\
\hline $\mathrm{NO}_{2}$ & $\sqrt{ }$ & $\sqrt{ }$ & $\sqrt{ }$ & $\sqrt{ }$ & $\sqrt{ }$ & $\sqrt{ }$ & $\sqrt{ }$ & $\sqrt{ }$ & $\sqrt{ }$ & $\sqrt{ }$ & 100.0 \\
\hline $\mathrm{TN}$ & & $\sqrt{ }$ & $\sqrt{ }$ & $\sqrt{ }$ & $\sqrt{ }$ & $\sqrt{ }$ & $\sqrt{ }$ & $\sqrt{ }$ & $\sqrt{ }$ & $\sqrt{ }$ & 90.0 \\
\hline $\mathrm{TP}$ & & & $\sqrt{ }$ & $\sqrt{ }$ & $\sqrt{ }$ & $\sqrt{ }$ & $\sqrt{ }$ & & & $\sqrt{ }$ & 60.0 \\
\hline $\mathrm{PO}_{4}{ }^{3-}$ & $\sqrt{ }$ & $\sqrt{ }$ & & $\sqrt{ }$ & $\sqrt{ }$ & $\sqrt{ }$ & $\sqrt{ }$ & & $\sqrt{ }$ & $\sqrt{ }$ & 80.0 \\
\hline $\mathrm{Fe}$ & $\sqrt{ }$ & $\sqrt{ }$ & $\sqrt{ }$ & $\sqrt{ }$ & $\sqrt{ }$ & $\sqrt{ }$ & $\sqrt{ }$ & $\sqrt{ }$ & $\sqrt{ }$ & $\sqrt{ }$ & 100.0 \\
\hline $\mathrm{Cd}$ & $\sqrt{ }$ & $\sqrt{ }$ & $\sqrt{ }$ & $\sqrt{ }$ & $\sqrt{ }$ & $\sqrt{ }$ & $\sqrt{ }$ & $\sqrt{ }$ & $\sqrt{ }$ & $\sqrt{ }$ & 100.0 \\
\hline $\mathrm{Zn}$ & $\sqrt{ }$ & $\sqrt{ }$ & $\sqrt{ }$ & $\sqrt{ }$ & $\sqrt{ }$ & $\sqrt{ }$ & $\sqrt{ }$ & $\sqrt{ }$ & $\sqrt{ }$ & $\sqrt{ }$ & 100.0 \\
\hline $\mathrm{Hg}$ & $\sqrt{ }$ & $\sqrt{ }$ & $\sqrt{ }$ & & & $\sqrt{ }$ & & & $\sqrt{ }$ & $\sqrt{ }$ & 60.0 \\
\hline $\mathrm{Cu}$ & $\sqrt{ }$ & $\sqrt{ }$ & $\sqrt{ }$ & $\sqrt{ }$ & $\sqrt{ }$ & $\sqrt{ }$ & $\sqrt{ }$ & $\sqrt{ }$ & $\sqrt{ }$ & $\sqrt{ }$ & 100.0 \\
\hline $\mathrm{Mn}$ & $\sqrt{ }$ & $\sqrt{ }$ & $\sqrt{ }$ & $\sqrt{ }$ & $\sqrt{ }$ & $\sqrt{ }$ & $\sqrt{ }$ & $\sqrt{ }$ & $\sqrt{ }$ & $\sqrt{ }$ & 100.0 \\
\hline $\mathrm{Pb}$ & $\sqrt{ }$ & $\sqrt{ }$ & $\sqrt{ }$ & $\sqrt{ }$ & $\sqrt{ }$ & $\sqrt{ }$ & $\sqrt{ }$ & $\sqrt{ }$ & $\sqrt{ }$ & $\sqrt{ }$ & 100.0 \\
\hline $\mathrm{Cr}$ & $\sqrt{ }$ & $\sqrt{ }$ & $\sqrt{ }$ & $\sqrt{ }$ & $\sqrt{ }$ & $\sqrt{ }$ & $\sqrt{ }$ & $\sqrt{ }$ & $\sqrt{ }$ & $\sqrt{ }$ & 100.0 \\
\hline TVC & $\sqrt{ }$ & $\sqrt{ }$ & $\sqrt{ }$ & & & $\sqrt{ }$ & $\sqrt{ }$ & $\sqrt{ }$ & $\sqrt{ }$ & $\sqrt{ }$ & 80.0 \\
\hline Ecol & $\sqrt{ }$ & $\sqrt{ }$ & $\sqrt{ }$ & $\sqrt{ }$ & $\sqrt{ }$ & $\sqrt{ }$ & $\sqrt{ }$ & $\sqrt{ }$ & & $\sqrt{ }$ & 100.0 \\
\hline Fcol & $\sqrt{ }$ & $\sqrt{ }$ & $\sqrt{ }$ & $\sqrt{ }$ & $\sqrt{ }$ & $\sqrt{ }$ & $\sqrt{ }$ & $\sqrt{ }$ & $\sqrt{ }$ & $\sqrt{ }$ & 100.0 \\
\hline $\begin{array}{l}\text { No of critical } \\
\text { indicators }\end{array}$ & 19 & 22 & 22 & 21 & 21 & 22 & 23 & 21 & 22 & 23 & \\
\hline $\begin{array}{l}\% \text { Cumulative } \\
\text { variation } \\
\text { explained }\end{array}$ & 92.6 & 96.2 & 95.3 & 93.2 & 92.9 & 94.0 & 94.8 & 94.8 & 91.8 & 90.6 & \\
\hline
\end{tabular}


tion. Out of 26 parameters monitored, the numbers of critical indicators listed by the PCs ranged from $19-23$. OFI and OF4 had the largest indicators (23), while OG1 has the least (19).

From Table 5, the parameters that have variable inclusion level (VIL) of $70-100 \%$ are of significant importance in the watershed. Other variables have VIL that are less than $70 \%$. The water quality monitoring therefore, may not employ all the parameters listed in each of the locations. This is contrary to the practice of using variables that are important in a watershed in the assessment of another watershed without answering the question of relevance and adequacy. The choice of indicators should be based on major factors driving pollution within the area. Ouyang et al. (2006) had earlier observed from a study of water quality in lower St John's river basin, USA that the variables that are important in a season are not exactly the same in another season.

Thus, 20 out of the 26 investigated variables are considered important and should be given utmost attention as basic indicators in monitoring and assessment of water quality in the Ogun watershed. This high number of pollutants not only confirms the extent of the pollution of the watershed, but also the near homogeneity of water quality impairment across the locations.

\section{CONCLUSION}

This study has shown that the management of water resources system is not complete without adequate assessment of variables that influence the surface water health status. The use of location PCA has shown that major pollutant of a river system could be identified without compromising the integrity of investigation. As a follow up to the PCA, evaluation of inclusion level of each variable enabled the spread of the critical variables in a watershed. The high number of parameters, which are of critical importance in monitoring water quality status in the Ogun watershed is an indication of high level of impairment of Ogun and Ofiki River sys- tems. This calls for better attention to the management of land-use in the watershed and the enforcement of pollution control regulations.

\section{REFERENCES}

Adedokun, O. A., Adeyemo, O. K., Adeleye, E. and Yusuf, R.K. (2008). Seasonal Limnological variation and nutrient load of the River system in Ibadan Metropolis. European Journal of Scientific Research, 23 (1): 98-108.

Ajibade, L. T. (2004) Assessment of Water Quality along River Asa, Ilorin Nigeria. The Environmentalist, 24: 11-18.

American Public Health Association (APHA ) (1998). Standard methods for the examination of water and wastewater, APHA, 20th Ed., Washington, DC, 20th Ed., Washington 2-1 - 4-135

Cansu, F. I., Arzu, A., Birdal, S. and Serhan, Y. H. (2009). Evaluation of surface water quality characteristics by using multivariate statistical techniques: A case study of the Euphrates river basin, Turkey. Environmental Monitoring and Assessment, 151 (2): 259 264.

Emmanuel, E., Odjadjare, O. and Anthony, I. O. (2010). Physicochemical quality of an urban Municipal wastewater effluent and its impact on the receiving environment. Environmental Monitoring and Assessment, 170 (3): 383-394.

Emoyan, O. O., Ogban, F. E. and Akarah, E. (2006). Evaluation of Heavy Metals Loading of River Ijanna in Ekpan - Warri, Nigeria. Journal of Applied Science Environment and Management, 10 (2) : 121-127.

Fiona, B., Grant, A. H. and Andrew, J. H. (2010). Affluent effluent: growing vegetables with wastewater in Melbourne, Australia - a wealthy but bone-dry city. Irrigation Drainage System, 24: 79-94. 
Global Environmental Monitoring Systems (GEMS) (2007). Global Drinking Water Quality Index Development and Sensitivity Analysis Report. United Nations Environment Programme. GEMS Water Programme.

Gilbert, M. M. (1996). Introduction to Environmental Engineering. 2nd Edition. Prentice Hall Upper Side, River New Jersey.

Harley, T. D., Aelion, C. M., McDermott, S., and Lawson, A. B. (2009). Identifying Natural and Anthropogenic Sources of Metals in Urban and Rural Soils using GIS-based data, PCA and spatial interpolation. Environmental Pollution 157 (8-9): 2378 - 2385.

Helsel, D.R. and Hirsch, H. M. (2002). Statistical methods in Water Resources. Techniques in Water Resources Investigation. United States Geological Services

Jaji, M. O., Bamgbose, O., Odukoya, O. O. and Arowolo, T. A. (2007). Water quality assessment of Ogun river, South West Nigeria. Environment Monitoring and Assessment, 133 (3): 473-482.

Karim, B. and Taha, F. M. (2003). Using Principal Component Analysis to monitor spatial and Temporal changes in water quality. Journal of Hazardous Materials. B100. 179- 195.

Martins, O. and Awokola, O. S. (1996). Total dissolved solids of selected rivers in SouthWestern Nigeria. Journal of Mining and Geology, 32(2): 113-119.

Meybec, K. M., Kimstach, V. and Helmer, R. (1996). Strategies for water quality assessment - In Deborah C. (Ed): A Guide to Use of Biota, Sediments and Water in Environmental Monitoring. UNESCO/WHO/UNEP, 40-73.
NIS, (2007). Nigerian Industrial Standard: Nigerian Standard for Drinking Water Quality NIS 554: $14-21$

Nyenje, P. M., Foppen, J. W., Uhlenbrook, S., Kulabako, R. and Muwanga, A. (2010). Eutrophication and nutrient release in urban areas of sub-Saharan Africa - A review. Science of Total Environment, 408: 447-455.

Ogun Osun River Basin Authority (1996). OORBDA Publication. Nigeria.

Oluwatosin, G. A., Adeyolanu, O. D., Ojo, A. O., Are, K. S., Dauda, T. O. and Aduramigba -Modupe, V. O. (2009). Heavy Metal Uptake and Accumulation by Edible Leafy Vegetable (Amaranthus Hybridus L.) Grown on Urban Valley Bottom Soils in Southwestern Nigeria. Soil and Sediment Contamination, 19 (1): 1 - 20 .

Ouyang, Y., Nkedi-Kizza, P., Wu, Q. T., Shinde, D. and Huang, C. H. (2006). Assessment of Seasonal Variations in Surface Water Quality. Water Research, 40: 3800 3810 .

Ruth, F. W. and Mathew, A. M. (2003) Environmental Engineering. 4th. Edition: Butterworth and Heineman, Elsevier Science. USA.

Shrestha, S. and Kazama, F. (2007). Assessment of surface water quality using multivariate statistical techniques: A case study of the Fuji River Basin, Japan. Environmental Modelling and Software, 22 (4): 464-475.

World Health Organization (2011).Guidelines for Drinking-water quality. $4^{\text {th }}$ Edition World Health Organization. Geneva. 